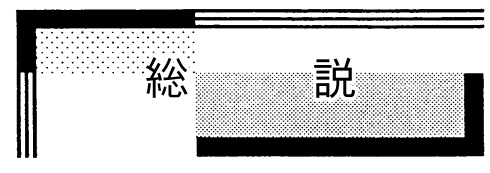

\title{
空気流による付着性粉体のオリフィスからの噴出現象* \\ Spouting Phenomenon of Cohesive Powder from an Orifice using Air Flow
}

\author{
尾 形 公 一 郎** \\ OGATA Koichiro
}

\begin{abstract}
This study experimentally examined the spouting phenomenon of the cohesive powder from an orifice when air was supplied from the top and the bottom of powder bed in a vessel. The stable discharge of the cohesive powder was obtained as the same flow rate of air was simultaneously supplied at the top and the bottom of the powder bed. Then, it was observed that the flow pattern of powder bed in a vessel became a mass flow, and that the discharged powder jet from an orifice was dispersed in the atmosphere. It was found that the interstitial air pressure affected the change of the void fraction and the discharge coefficient. In addition, it was confirmed that the interstitial air pressure during the spouting of powder greatly influenced the mass flow rate of powder through an orifice.
\end{abstract}

Keywords: Cohesive powder, Powder jet, Void fraction, Interstitial air pressure, Mass flow rate

\section{1. はじめに}

近年、様々な産業分野で微細化した粉体を取扱 う機会が増えており、粉体の単位操作技術の向上 が求められている。これは、粉体は比表面積が大 きく反応性などに優れるためである。しかしなが ら、一般に、粉体は粒子径が小さくなると付着性 の影響を受けて流動性が悪くなることが知られ ている。特に、粉体を空気中でハンドリングする 場合、粉体の付着・凝集に伴う閉塞などによって、 容器からの排出停止や粉体が突発的に流出して 制御不能となるフラッシングなどの問題を生じ る[1]。このため、付着性粉体の円滑な排出操作の 知見を得ることは重要である。その操作の一つに、 粉体を空気流で容器から排出(本稿で取扱う流れ は粉体が空気流でオリフィスから勢いよく流出 する現象であるため、以下、噴出と呼ぶ）する方 法がある。

ここで、容器内に充てんした粉体を空気流で才 リフィスから噴出する研究を述べる。このような
研究は多くの理論的、実験的研究がなされてきた [2-11]。これらの研究は、粉体の気流中での流動 化特性の指標の一つである Geldart 線図で整理で きる。Geldart 線図[12,13]とは、粒子径と粒子と 流体の密度差で粉体の流動化特性を C、A、B、D の 4 つのグループに分類したものである。この中 で、グループ A、B 及び D 粒子は流動化が可能な 粒子である。一方、グループ C 粒子は粒子径が小 さいため付着性の影響が大きく、流動化がしにく いとされている。このことを踏まえて、空気流に よるオリフィスからの噴出に関する研究をまと めると、流動化が可能なグループ B 及び D 粒子 に対して、容器内に充てんした粉体の上部や底部 に空気を供給して、噴出特性を調査したものが多 く見られる[2-7]。また、気流や付着力などの影 響が強くなる、グループ A 及び C 粒子を対象と した研究[7-11]もあるが、特に、C 粒子は流動化 噴出が困難な場合や非定常な流動特性が存在す る[9-11]。さらに、粉体に与える空気の供給位置

* 2012.1.26 受付

** 大島商船高等専門学校電子機械工学科 ₹742-2193 山口県大島郡周防大島町小松 1091-1

TEL: (0820)74-5487 FAX: (0820)74-5487 E-mail: ogata@oshima-k.ac.jp 
を変化させて、オリフィスからの粉体の噴出に及 ぼす空気流の影響や操作性などを検討した研究 は僅かである[6]。以上のことから、気流や付着性 の影響が大きくなるグループ A 及び C 粒子の空 気流による噴出に関する知見は十分ではないと 考えられる。

このような背景から、筆者は空気流による付着 性粉体 (ここでは、容器底部のオリフィスからの 重力排出が困難なグループ A 及び C 粒子) の定 量噴出に関寸る研究を進めている[14-16]。その 操作は、密閉容器内に充てんした粉体層の上部之 底部へ空気を供給して、粉体を定量噴出しょうと するものである。本稿では、筆者がこれまでに実 施してきた、空気流による付着性粉体の定量噴出 操作、噴出特性や粉体流動について述べる。

\section{2. 実験}

\section{1 実験装置と方法}

Fig.1 に実験装置の概略を示す。実験装置は、 粉体充てん部、空気供給部、粉体充てん部へ空気 を透過する多孔材と粉体回収部から成る。粉体一 供給する空気はコンプレッサーで生成し、エアク リーナー、オイルミストセパレーター、減圧弁を 通して、マスフローコントローラーへ導く。空気 流量はマスフローコントローラーで設定する。実 験は内径 $D_{v}$ が $50 \mathrm{~mm}$ 、高さ $150 \mathrm{~mm}$ のアクリル製 円筒容器に粉体を充てんした後、容器上部と底部 に設置した厚さ $6 \mathrm{~mm}$ の多孔材を通して、粉体層 の上部と底部へ同一の空気流量を同時に供給す る。この時、粉体は容器底部中央の直径 $4 \mathrm{~mm} の$ 円形オリフィスから噴出される。

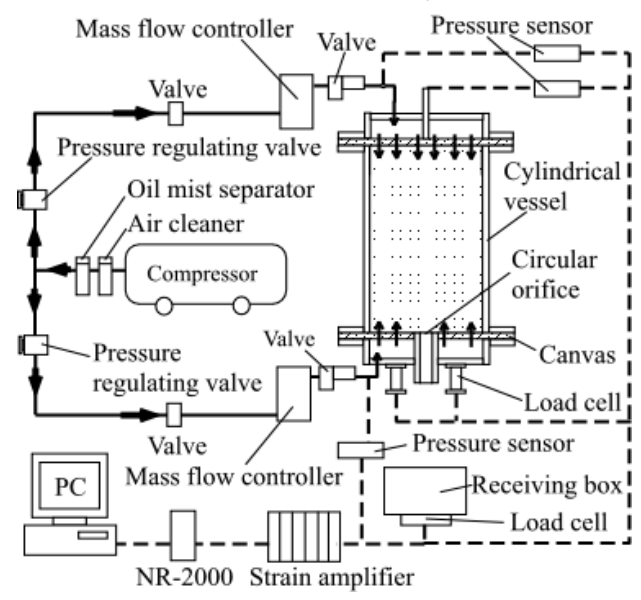

Fig. 1 Schematic of experimental apparatus.
実験では、粉体噴出量 $M_{p}$ をロードセルで、粉 体層上部の空隙流体圧 $p_{a}$ を圧力センサで測定し た。また、噴出中の粉体層高さ $H$ や大気中へ噴 出する粉体流動をデジタルビデオカメラで撮影 した。実験中に得られたロードセル、圧力センサ とマスフローコントローラーの信号は動ひずみ 計、データ収録装置を介して、パーソナルコンピ ユーターで噴出量と圧力、空気流量の時系列デー タを取得した。また、データ収録装置、パーソナ ルコンピューターとデジタルビデオカメラの時 刻を合わせることで、各種測定值とフローパター ンの同時計測を可能とした。

\section{2 使用粒子及び実験条件}

Table 1 に小麦粉とシリカ粒子の粒子物性值を 示す。表中の $d_{p}$ は平均粒子直径、 $\rho_{p}$ は粒子の真 密度である。本研究で用いた小麦粉は、Geldart 線図中の A 粒子に属するが、オリフィスからの 重力排出が困難な粉体である。また、シリカ粒子 は Geldart 線図中の C 粒子で気流による流動化が しにくい粉体に分類される。

Table 2、3 に小麦粉とシリカ粒子の実験条件を 示す。ここで、 $M_{p i}$ は粉体の初期充てん量、 $H_{i}$ は 粉体層の初期高さ、 $\varepsilon_{i}$ は初期空隙率、 $Q_{t}$ と $Q_{b}$ は 粉体層上部と底部へ供給する空気流量である。ま た、本研究では、粉体噴出中の粉体層の平均空隙 率 $\varepsilon$ を次式で算出した。

$$
\varepsilon=1-\frac{\rho_{b}}{\rho_{p}}=1-\frac{4 M_{r}}{\pi D_{v}^{2} H \rho_{p}}
$$

ここで、 $\rho_{b}$ は粉体のかさ密度、 $M_{r}$ は容器内の粉 体層の残留質量 $M_{r}=M_{p i}-M_{p}$ である。

Table 1 Particle properties.

\begin{tabular}{ccc}
\hline & $d_{p}(\mu \mathrm{m})$ & $\rho_{p}\left(\mathrm{~kg} / \mathrm{m}^{3}\right)$ \\
\hline Wheat flour & 46 & 1493 \\
Silica & 15.6 & 2200 \\
\hline
\end{tabular}

Table 2 Experimental conditions (Wheat flour).

\begin{tabular}{cccc}
\hline$M_{p i}(\mathrm{~g})$ & $H_{i}(\mathrm{~mm})$ & $\mathcal{E}_{i}(-)$ & $Q_{i}=Q_{b}\left(\times 10^{-5} \mathrm{~m}^{3} / \mathrm{s}\right)$ \\
\hline 100 & $83 \sim 85$ & $0.589 \sim 0.599$ & \\
100 & $95 \sim 96$ & $0.641 \sim 0.645$ & $1.7,3.3,5.0$ \\
100 & $112 \sim 113$ & $0.695 \sim 0.698$ & $6.7,10.0$ \\
98 & $120 \sim 125$ & $0.721 \sim 0.733$ & $13.3,16.7$ \\
\hline
\end{tabular}


Table 3 Experimental conditions (Silica powder).

\begin{tabular}{cccc}
\hline$M_{p i}(\mathrm{~g})$ & $H_{i}(\mathrm{~mm})$ & $\varepsilon_{i}(-)$ & $Q_{t}=Q_{b}\left(\times 10^{-5} \mathrm{~m}^{3} / \mathrm{s}\right)$ \\
\hline 200 & $84 \sim 85$ & $0.449 \sim 0.455$ & $2.666 \sim 8.333$ \\
200 & $92 \sim 93$ & $0.496 \sim 0.502$ & $0.166 \sim 2.5$ \\
200 & $101 \sim 102$ & $0.537 \sim 0.546$ & $0.166 \sim 2.5$ \\
\hline
\end{tabular}

\section{3. 噴出モデル}

オリフィスから粉体が定量噴出していること を評価するためには、粉体の単位時間当りの噴出 量が一定であることが一つの指標となる。このた め、空気流によって噴出する粉体の単位時間当た りの噴出量 $m_{p}$ に対して種々のモデルが提案され ている。本研究の粉体流動を考えると、既存のモ デルと同様に、空気流による粉体のオリフィスか らの噴出には、噴出中の粉体層に作用する空隙流 体圧や空隙率が大きく影響すると思われる。そこ で、本研究の流れ場での粉体の単位時間当りの噴 出量に対する空隙率や空隙流体圧の影響を簡略 化して知るために、De Jong [4]やGeldartら[7]と同 様の流動モデルを用いて、単位時間当たりの噴出 量に及ぼす空隙率や空隙流体圧の影響を調査し た。

本研究で用いた流動モデルは次の通りである。 まず、空気流によって流動する粉体を非圧縮、非 粘性流体と仮定して、ベルヌーイの定理により噴 出速度を表す。ここで、実験結果から、単位時間 当たりの噴出量に対する粉体層高さHの影響は あまり見られないので、De Jong と同様に、噴出 速度に対する重力項の影響は無視するものとし、 $\Delta p=p_{a}, \rho=\rho_{b}=(1-\varepsilon) \rho_{p}$ とおくと、オリフィスから の粉体の噴出速度 $v$ は式(2)で表される。

$$
\begin{aligned}
v & =\sqrt{2\{g H+(\Delta p / \rho)\}} \\
& =\sqrt{2 p_{a} /(1-\varepsilon) \rho_{p}}
\end{aligned}
$$

次に、De Jong と同様に、オリフィスからの粉 体の単位時間当たりの噴出量 $m_{p}$ を式(3)で表す。

$$
\begin{aligned}
m_{p} & =C A(1-\varepsilon) \rho_{p} v \\
& =C \frac{\pi}{4}\left(D-k d_{p}\right)^{2} \sqrt{2(1-\varepsilon) \rho_{p} p_{a}}
\end{aligned}
$$

ここで、Dはオリフィス直径、Cは供給係数、 $k$ は 粒子の形状係数である。式(3)中の定数をまとめる と次式となる。

$$
m_{p}=B C_{a v} \sqrt{\left(1-\varepsilon_{a v}\right) p_{a v}}
$$

式(4)中の $B$ は定数をまとめたもの、添え字 $a v$ は各值の平均值を表す。式(4)より、空気流による 粉体の単位時間当たりの噴出量は空隙率、空隙流 体圧、供給係数の関係で整理できる。

\section{4. $\mathrm{A}$ 粒子の噴出特性[14,15]}

まず、密閉容器内に充てんした粉体を定量噴出 するための空気供給位置について調查した結果 を述べる。本章では、オリフィスからの重力排出 が困難で、Geldart 線図中の A 粒子に属する小麦 粉を使用した結果を示す。

\section{1 空気供給位置による粉体噴出特性}

Fig.2 に、充てん容器内の粉体層の上部から空 気を供給して粉体をオリフィスから噴出した場 合の特徵的なフローパターンを示す。Fig.2(a)は 粉体噴出時の空気と粒子運動の模式図、Fig.2(b) は粉体層上部からの撮影画像である。ここで、 $\varepsilon_{i}=0.659 、 Q_{i}=10 \times 10^{-5} \mathrm{~m}^{3} / \mathrm{s}$ である。図のように、 この空気供給方法では、Fig.2(a)のように、粉体 層上部からオリフィスへ向から空気流が支配的 で層全体の流動は行われない様子が確認された。 また、Fig.2(b)のように、層の外側は静止状態で、 層内部の粉体のみが強制的に噴出するラットホ 一ルのような流動が見られた。このように、粉体 層の上部から空気を供給する方法では、粉体の良 好な噴出状態が得られないことが分かる。

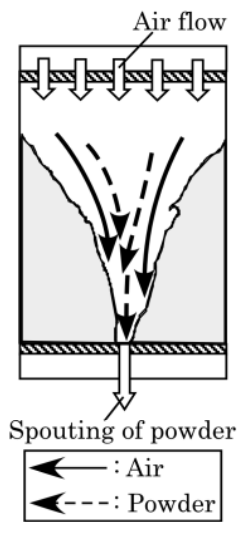

(a)Flow pattern

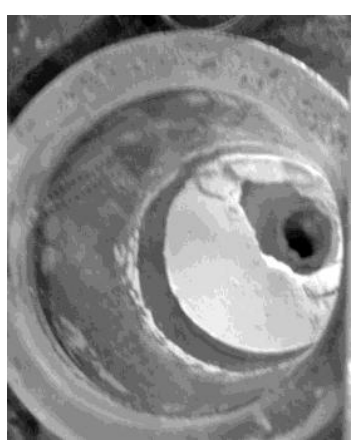

(b) Top view of bed
Fig. 2 Flow pattern in a vessel at the spouting of powder when air was introduced only at the top of powder bed, $\varepsilon_{i}=0.659, \quad Q_{t}=10 \times$ $10^{-5} \mathrm{~m}^{3} / \mathrm{s}$. 
Fig.3 に、粉体層の底部から空気を供給して、 粉体を噴出した場合の空気と粒子運動の模式図 と粉体層側面からの撮影画像を示す。ここで、 $\varepsilon_{i}=0.652 、 Q_{b}=10 \times 10^{-5} \mathrm{~m}^{3} / \mathrm{s}$ である。この空気供給 方法では、Fig.3(a)のように、粉体層底部に供給 した空気流が層内を通気し、かつ、層内の圧力上 昇が起こることで、粉体層を流動化噴出する流れ が形成されると考えられる。粉体噴出中の容器内 の粉体運動を観察すると、Fig.3(b)のように、層 内を通気する空気流の影響で粉体層はクラック や層分離を起こしながら、分離した粉体層が上部 へ大きく上昇する様子が見られた。このような粉 体流動は、層上部が大気開放の条件で粉体層の底 部から流動化噴出させた場合にも確認されてい る $[9,11]$ 。本研究で実施した粉体層の底部に空気 流を供給する噴出操作では、粉体層の分離や層の 上下振幅が見られた場合に、オリフィスからの粉 体の噴出量や空隙流体圧が非定常に変化する流 れが現れた。このため、本方法では粉体の定量噴 出が不可能な条件が存在することが明らかとな った。

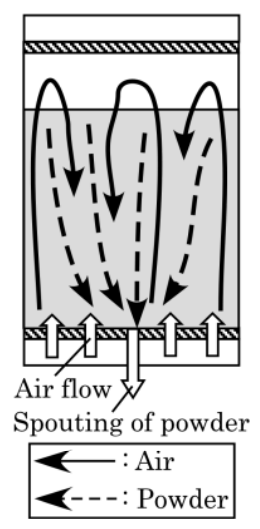

(a)Flow pattern

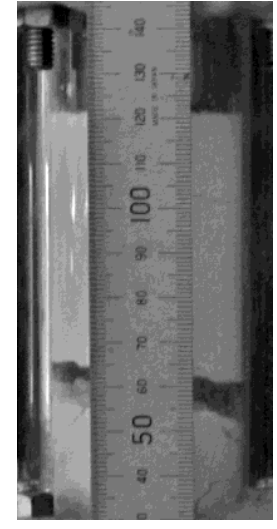

(b) Side view of bed
Fig.3 Flow pattern in a vessel at the spouting of powder when air was introduced only at the bottom of powder bed, $\varepsilon_{i}=0.652, Q_{b}=10 \times$ $10^{-5} \mathrm{~m}^{3} / \mathrm{s}$.

次に、密閉容器内の粉体層の上部と底部から同 一の空気流量を同時に供給した場合の粉体流動 と噴出特性について述べる。Fig.4 に、粉体噴出 中の容器内の粉体層のフローパターンの模式図 を示す。この結果は、実験で粉体の噴出が可能で あった条件の可視化から得られたものである。図
のように、本空気供給方法では、容器内の粉体は 層全体が平均的に低下し、容器内に先に充てんし た粉体から噴出するようなマスフロー流動を維 持しながら、容器底部のオリフィスからの粉体の 噴出が実現できていた。これは、本方法では、粉 体層上部と底部へ供給した空気流によって、(1) 底部からの空気流による粉体層の流動化特性の 向上、(2)上部からの空気流による層上昇の抑制効 果と (3)層内の空隙流体圧の上昇により発生する 空気流が相互に影響寸ることで、粉体のオリフィ スからの噴出が実現できたと考えられる。

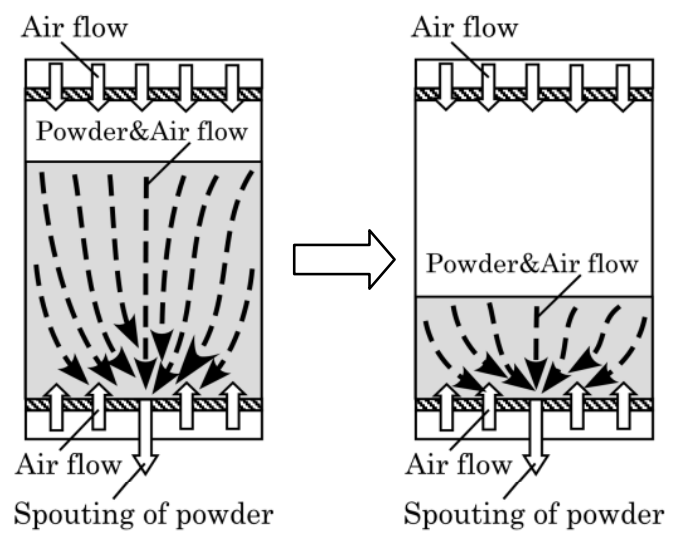

Fig.4 Flow pattern of mass flow condition during the spouting of powder.

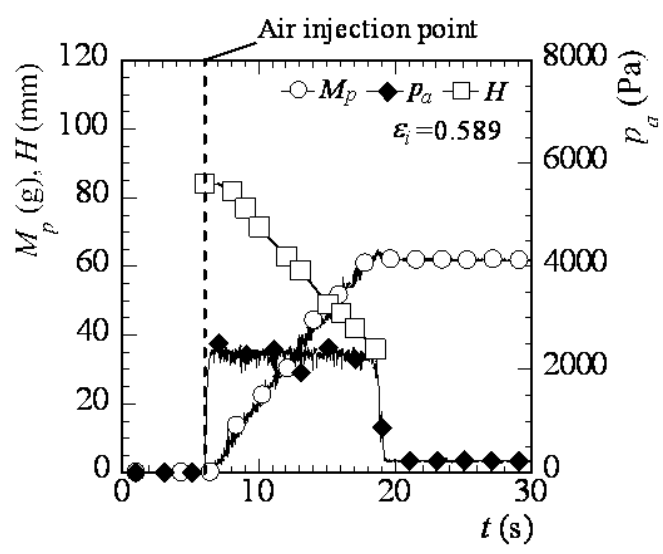

Fig.5 Time histories of the cumulative mass of powder, the interstitial air pressure and the height of bed when air was introduced at the top and the bottom of powder bed, $\varepsilon_{i}=0.589$, $Q_{t}=Q_{b}=10 \times 10^{-5} \mathrm{~m}^{3} / \mathrm{s}$.

Fig.5 に、初期空隙率 $\varepsilon_{i}=0.589$ の場合の粉体噴出 
量 $M_{p}$ 、粉体層上部の空隙流体圧 $p_{a}$ と粉体層高さ $H$ の時間変化を示す。ここで、 $Q_{t}=Q_{b}=10 \times 10^{-5} \mathrm{~m}^{3} / \mathrm{s}$ で同一とし、粉体層へ同時に空気を供給した。図 より、空気供給直後から粉体はオリフィスからの 噴出を開始し、粉体噴出量はほぼ一定の傾きを取 ることが分かる。これは、オリフィスから噴出す る粉体の単位時間当りの噴出量がほぼ一定で、粉 体の定量噴出が実現できていることを示してい る。また、粉体層上部の空隙流体圧は空気供給後 に急激に増加し、噴出中は任意の圧力を保つこと や、粉体層高さは時間経過とともに一定の傾きで 減少することが分かる。

Figs.4、5 の結果から、粉体層の上部と底部一 空気を供給する操作方法は重力排出が困難な粉 体である小麦粉をほぼ一定の単位時間当たりの 噴出量で噴出可能であり、粉体の定量噴出に対し て有効な操作方法であることが理解できる。

\section{2 粉体噴出中の空隙率と空隙流体圧の特性}

Fig.6 に、粉体層の上部と底部へ同一の空気を 供給した場合の粉体噴出時の容器内の粉体層の 平均空隙率 $\varepsilon$ 之粉体層高さ $H$ の関係を示す。ここ で、初期空隙率 $\varepsilon_{i}=0.721 \sim 0.733$ でほぼ一定とし、 粉体層への供給空気流量 $Q_{t}$ と $Q_{b}$ を変化させた。 図より、平均空隙率は多少のばらつきは見られる ものの、粉体層高さの減少に伴い、その值を僅か に増加させることが分かった。また、粉体層へ供 給する空気流量の増加とともに平均空隙率は全 体的に増加する傾向が見られた。

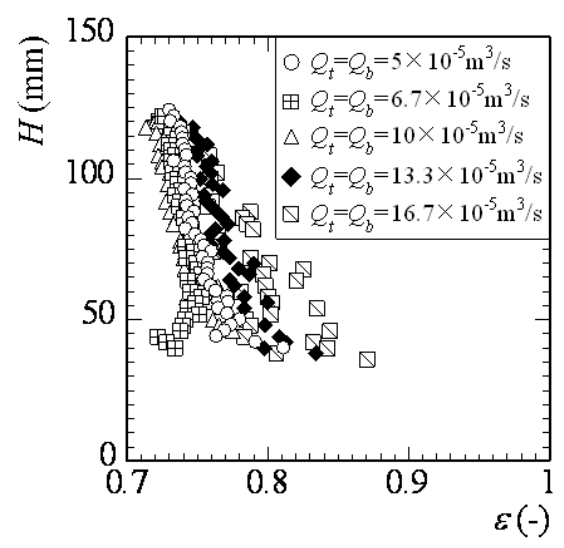

Fig.6 Relationship between the void fraction and the height of powder bed during the spouting of powder.
次に、Fig.7 に、粉体噴出中の粉体層上部の空 隙流体圧 $p_{a}$ と粉体層高さ $H$ の関係を示す。図よ り、多少の変動は見られるものの、粉体噴出中の 層上部の空隙流体圧は任意の圧力を保持してい ることが分かる。さらに、粉体層へ供給する空気 流量の増加とともに空隙流体圧は増加寸る傾向 が見られる。このことは、供給空気流量の増加に よって粒子層に作用する外力が大きくなること を示している。

以上をまとめると、粉体層の上部と底部から空 気を供給した場合の容器内の粉体流動は、粉体層 の膨張による流動性の改善や、粉体層に作用寸る 空隙流体圧の影響によって、容器底部のオリフィ スからの粉体の良好な噴出特性を示すことが分 かる。

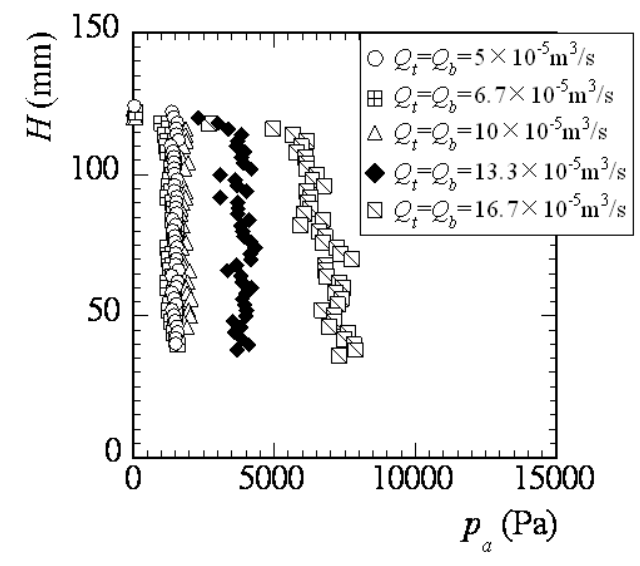

Fig.7 Relationship between the interstitial air pressure and the height of powder bed during the spouting of powder.

\section{C 粒子の噴出特性[16]}

前章の結果から、密閉容器内の粉体をオリフィ スから定量噴出させるためには、粉体層の上部と 底部から空気を供給する方法が有効であること が明らかになった。そこで、本章では、空気中で の流動化がしにくい粉体である Geldart 線図中の $\mathrm{C}$ 粒子に分類されるシリカ粒子に対して、この空 気供給方法を導入し、粉体の定量噴出が可能であ るかを調査した結果について述べる。

\section{1 噴出中の粉体流動}

Fig.8 に、粉体層の上部と底部から同一の空気 流量を同時に供給して粉体を噴出する場合の容 器内のフローパターンを示す。使用粒子はシリカ 
粒子で、初期空隙率 $\varepsilon_{i}=0.546$ 、層上部と底部への 供給空気流量 $Q_{t}=Q_{b}=0.5 \times 10^{-5} \mathrm{~m}^{3} / \mathrm{s}$ である。図より、 容器内の粉体は層全体が平均的に低下しながら 噴出することが分かる。この流れは、Fig.4 に示 した粉体流動と同じであり、粉体層の上部と底部 から空気を供給する操作方法が C 粒子の噴出に 対しても有効であることが分かる。また、同程度 の粒子径や粒子密度の粉体層底部に流動化空気 を与えた噴出実験では、容器内の粉体層に凝集や クラックが生じる非定常な流動が見られている $[9,11]$ 。これに対して、本空気供給方法による粉 体の流れは、容器に先に充てんした粉体から噴出 するマスフロー流動であり、層内に供給した空気 流によって良好な粉体流動を維持できているこ とが理解できる。

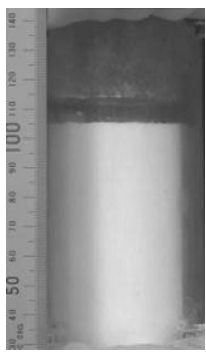

(a) $t=7 \mathrm{sec}$

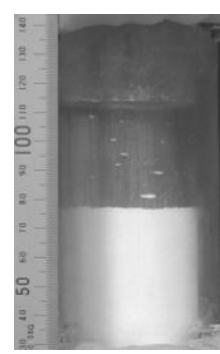

(b) $t=25 \mathrm{sec}$

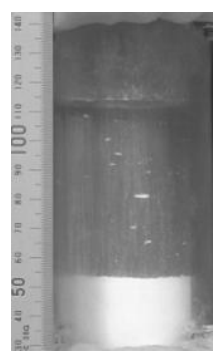

(c) $t=41 \mathrm{sec}$
Fig.8 Flow pattern of silica powder in a vessel when air was supplied from the top and the bottom of bed.

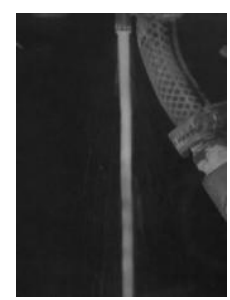

(a)

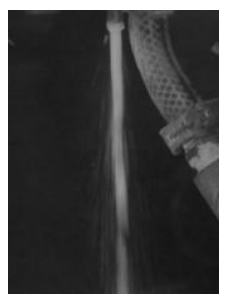

(b)

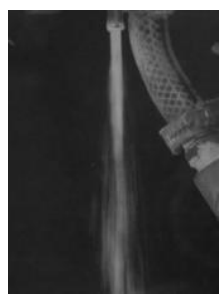

(c)
Fig.9 Behavior of powder jet during the spouting of powder from an orifice.

Fig.9 に、オリフィスから噴出する粉体の流れ を示す。実験条件は初期空隙率 $\varepsilon_{i}=0.544$, 供給空気 流量 $Q_{t}=Q_{b}=0.833 \times 10^{-5} \mathrm{~m}^{3} / \mathrm{s}$ である。図より、噴出 開始直後のオリフィス近傍部の流れは、粉体の半 径方向への分散はそれ程見られずに、粉体の鉛直
下向き方向への流れが支配的であることが確認 できる。一方、オリフィス出口部からの距離が増 加すると、粉体流動は半径方向に拡大し、粉体が 空間中に分散する様子が見られた。前述した粉体 層底部へ流動化空気を与えた噴出実験 $[9,11]$ では、 粉体が凝集した状態で大気中へ噴出しており、本 研究のような良好な分散特性は得られていなか った。

\section{2 粉体噴出に及ぼす影響因子}

Fig.10に、シリカ粒子の噴出量 $M_{p}$ 、粉体層上 部の空隙流体圧 $p_{a}$ と粉体層の平均空隙率 $\varepsilon$ の時間 変化を示す。ここで、実験条件は Fig.8 と同じで ある。図より、粉体噴出量は一定の傾きを取り、 単位時間当りの噴出量が一定であることが分か る。これは、本空気供給操作で Geldart 線図中の C 粒子に分類されるシリカ粒子の定量噴出が実 現可能であることを示している。この時、粉体層 上部の空隙流体圧は所定の圧力を保持し、平均空 隙率は僅かに増加する傾向が見られた。これらの 結果は、前章で示した小麦粉の噴出特性と同様で ある。

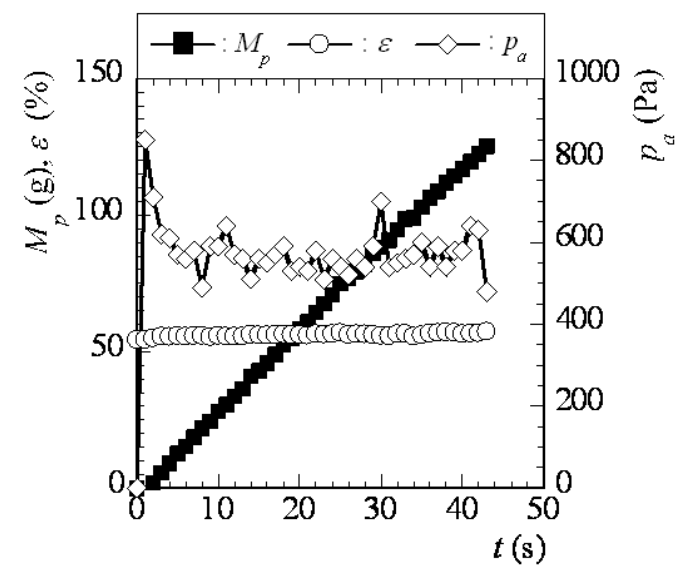

Fig.10 Time histories of the cumulative mass of powder, the interstitial air pressure and the void fraction.

次に、粉体層の上部と底部に空気流を与えた場 合の粉体の噴出に及ぼす影響因子を考える。3 章 で述べたように、粉体がオリフィスから定量的に 噴出していることを評価するためには、粉体の単 位時間当りの噴出量が一定であることが一つの 指標であり、式(4)から、単位時間当りの噴出量に は、空隙率、空隙流体圧と供給係数が影響すると 
思われる。そこで、これらの特性を調査した。

Fig. 11 に、各初期空隙率 $\varepsilon_{i}$ での粉体層の平均空 隙率 $\varepsilon_{a v}$ と層上部の平均空隙流体圧 $p_{a v}$ の関係を示 す。ここで、粉体層の平均空隙率と層上部の平均 空隙流体圧は各実験条件での粉体噴出時の值か ら平均值を算出した。図より、各初期空隙率の条 件での粉体層の平均空隙率は層上部の平均空隙 流体圧の増加とともに線形的に増加する傾向が 見られた。これは、噴出時の粉体層は層内に供給 した空気流で膨張し、粉体の流動性が改善されて いることを示唆している。さらに、この傾向から 粉体層の膨張特性は空隙流体圧の影響を大きく 受けることが理解できる。

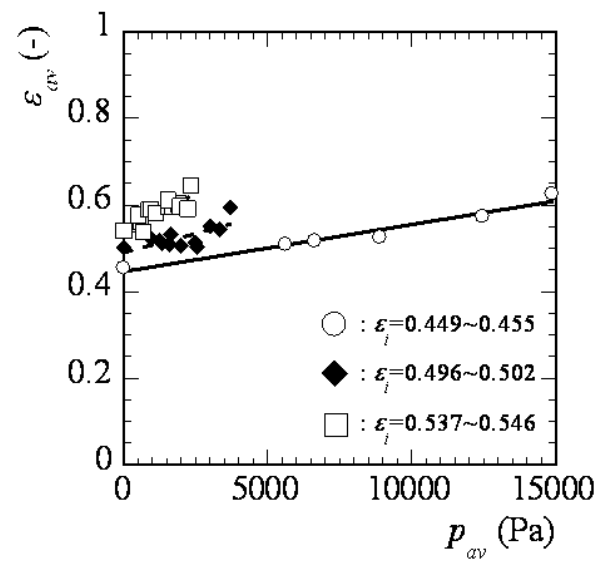

Fig.11 Relationship between the void fraction and the interstitial air pressure.

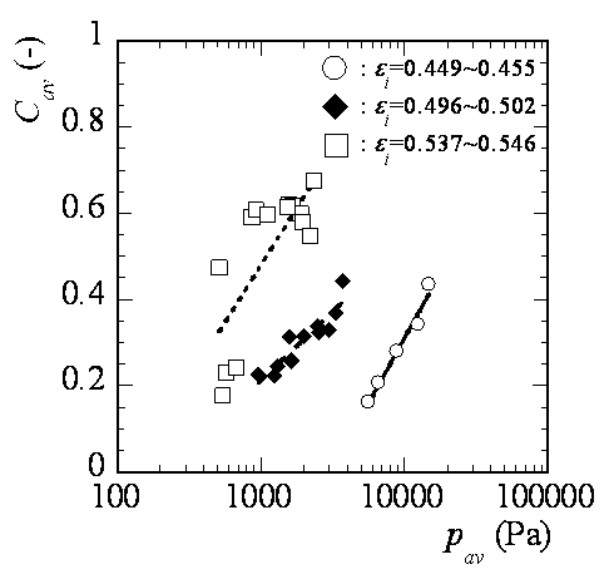

Fig.12 Relationship between the discharge coefficient and the interstitial air pressure.

Fig.12に、各初期空隙率における粉体噴出時の
平均供給係数 $C_{a v}$ と粉体層上部の平均空隙流体圧 $p_{a v}$ の関係を示す。ここで、供給係数は式(3)と実 験值から算出し、平均供給係数は Fig.11 と同様に 粉体噴出時の值を平均した。図より、多少のばら つきは見られるものの、平均供給係数は層上部の 平均空隙流体圧の増加とともに増加寸る傾向が 見られる。このことは、供給係数の変化が空隙流 体圧の影響を大きく受けることを表している。

Fig.13に、シリカ粒子の単位時間当りの噴出量 $m_{p}$ と粉体層上部の平均空隙流体圧 $p_{a v}$ の関係を示 す。図中の実線は式(4)の計算值である。図より、 単位時間当たりの噴出量は粉体層上部の空隙流 体圧の増加とともに増加する。また、Figs.11、 12 の結果から、粉体層の平均空隙率 $\varepsilon_{a v}$ と平均供 給係数 $C_{a v}$ は層上部の平均空隙流体圧に依存寸る ことが分かっている。Fig.13 と式(4)から、粉体層 へ供給した空気流で発生した層内の空隙流体圧 が粉体の噴出特性に大きく影響していることが 理解できる。

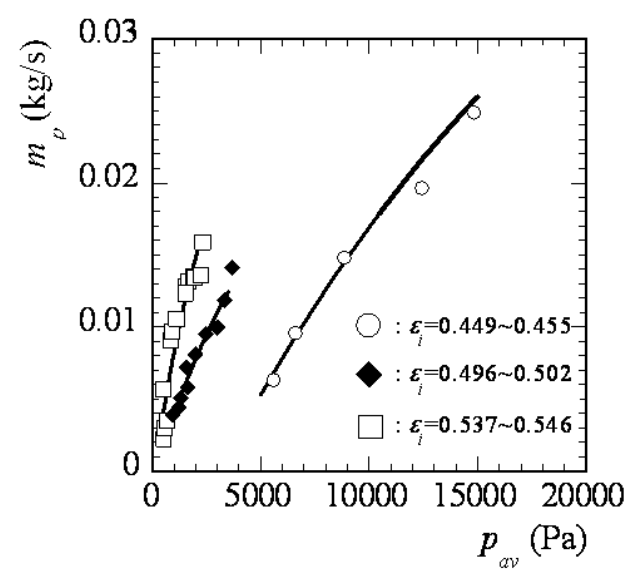

Fig.13 Relationship between the mass flow rate and the interstitial air pressure.

\section{6. まとめ}

本稿では、容器底部のオリフィスからの重力排 出が困難なGeldart線図中のグループA及びC粒子 を空気流でオリフィスから噴出する操作方法を 検討し、粉体の噴出特性や流動特性を示した。そ の結果、密閉容器内に充てんした粉体層の上部と 底部に空気を供給する操作が粉体の定量噴出に 対して有効であることを述べた。また、この操作 方法では、容器内の粉体層はマスフロー流動で、 
オリフィス噴出後の粉体は空間中に分散する良 好な流動特性を示した。さらに、定量噴出時の単 位時間当たりの噴出量には粉体層に作用する空 隙流体圧が大きな影響を与えることを述べた。

近年、産業界ではサブミクロン、ナノサイズの 粉体を取り扱う機会が増えており、その精密な八 ンドリングが求められている。本稿では、数十マ イクロサイズの粉体の空気流による噴出現象に 焦点を当てて議論したが、サブミクロンサイズの 粉体を対象とした流動化噴出に関する研究も進 められている[17]。しかしながら、この領域の粒 子に対する研究は十分とは言えない。今後は、本 研究で用いた空気供給方法などでサブミクロン、 ナノサイズの粉体の噴出特性や流動機構の解明 に取り組む予定である。

\section{謝 辞}

本研究は科学研究費補助金若手研究 B(No.16760143)で行われた。本研究の成果は本学 学生であった出井良和氏、高杉和成氏の多大なる 協力を得た。ここに記して、感謝の意を表する。

\section{Nomenclature}

C : discharge coefficient

$C_{a v} \quad$ : average discharge coefficient

$D \quad$ : orifice diameter

$d_{p} \quad$ : particle diameter

$H \quad$ : height of powder bed

$M_{p} \quad$ : cumulative mass of powder

$M_{r} \quad$ : residual mass of powder

$m_{p} \quad$ : mass flow rate of powder

$p_{a} \quad:$ interstitial air pressure

$p_{a v} \quad:$ average interstitial air pressure

$Q_{b} \quad$ : air flow rate to bottom of bed

$Q_{t} \quad$ : air flow rate to top of bed

$\varepsilon_{a v} \quad$ : average initial void fraction

$\varepsilon_{i} \quad$ : initial void fraction

$\varepsilon \quad:$ void fraction

$\rho_{b} \quad$ : bulk density

$\rho_{p} \quad$ : particle density

$[\mathrm{mm}]$

[m]

[mm]

[g]

[g]

$[\mathrm{kg} / \mathrm{s}]$

$[\mathrm{Pa}]$

$[\mathrm{Pa}]$

$\left[\mathrm{m}^{3} / \mathrm{s}\right]$

$\left[\mathrm{m}^{3} / \mathrm{s}\right]$

[-]

$[-]$

$[-]$

$\left[\mathrm{kg} / \mathrm{m}^{3}\right]$

$\left[\mathrm{kg} / \mathrm{m}^{3}\right]$

\section{参考文献}

[1] The Society of Powder Technology, Japan ed., Handbook of Powder Technology (in Japanese), 344-349, Nikkan Kogyo (1998)

[2] Kuwai, G., Flow of Solid Particles through Orifice, Chem. Eng. Sci. Jpn., Vol.17, 453-458
(1953).

[3] McDougall, I. R. and Knowles, G. H., Flow of Particles through Orifices, Trans. Inst. Chem. Engrs., Vol.47, T73-T78 (1969).

[4] De Jong, J. A. H., Vertical Air-controlled Particle Flow from a Bunker through Circular Orifices, Powder Technology, Vol.3, 279-286 (1969/70).

[5] De Jong, J. A. H., Aerated Solids Flow through a Vertical Standpipe below a Pneumatically Discharged Bunker, Powder Technology, Vol.12, 197-200 (1975).

[6] De Jong, J. A. H. and Hoelen, Q. E. J. J. M., Cocurrent Gas and Particle Flow during Pneumatic Discharge from a Bunker through an Orifice, Powder Technology, Vol.12, 201-208 (1975).

[7] Geldart, D. and Haesebrouck, M., Studies on the Intermittent Discharge of Coarse Solids from Fluidised Beds, Chem. Eng. Res. Des., Vol.61, 162-166 (1983).

[8] Martin, P. D. and Davidson, J. F., Flow of Powder through an Orifice from a Fluidized Bed, Chem. Eng. Res. Des., Vol.61, 225-232 (1983).

[9] Donsi, G., Ferrari, G., Poletto, M. and Russo, P., Aggregative Behavior of Cohesive Magnesium Carbonate Powders during Fluidization and Aerated Discharge, KONA, Vol.21, 54-65 (2003).

[10] Donsi, G., Ferrari, G., Poletto, M., and Russo, P., Gas Pressure Measurement inside an Aerated Hopper, Chem. Eng. Res. Des., Vol.82, 72-84 (2004).

[11] Barletta, D., Donsi, G., Ferrari, G., Poletto, M., and Russo, P., Solid Flow Rate Prediction in Silo Discharge of Aerated Cohesive Powders, AIChE Journal, Vol.53(9), 2240-2253 (2007).

[12] Geldart, D., Types of Gas Fluidization, Powder Technology, Vol.7, 285-292 (1973).

[13] Geldart, D., Williams, J. C., Flooding from Hoppers: Identifying Powder likely to give Problem, Aeration, Powder Technology, Vol.43, 181-183 (1985).

[14] Ogata, K., Spouting Phenomenon of Fluidized Fine Cohesive Powder, J. Soc. Powder Technol., Japan., Vol.45(12), 844-851 (2008).

[15] Ogata, K., Effect of Initial Void Fraction and Fluidized Air flow on Spouting of Fine Powder through an Orifice, J. Soc. Powder Technol., Japan., Vol.46(3), 187-196 (2009).

[16] Ogata, K., Spouting Phenomenon of Cohesive Fine Powder using Air Flow, JSMF Annual Meeting 2011, 302-303 (2011).

[17] Cannavacciuolo, A., Barletta, D., Donsi, G., Ferrari, G. and Poletto, M., Arch-Free Flow in Aerated Silo Discharge of Cohesive Powders, Powder Technology, Vol.191, 272-279 (2009). 